scientia studia, São Paulo, v. 3, n. 3, p. 4,15-41, 2005

\title{
st \\ A função do olho humano na óptica do final do século XvI
}

\author{
Claudemir Roque Tossato
}

\begin{abstract}
is
RESUMO

Neste artigo, trato em linhas gerais do papel do olho humano no desenvolvimento das teorias ópticas no período que vai da Grécia antiga até o final do século xvi. São destacados dois grandes momentos da história da óptica: a antiguidade e o século xıı. Procuro levantar alguns dos principais pontos relativos à importância do olho humano no ato da visão, relacionando esses pontos a três tradições de pesquisa que serviram como base para a elaboração de teorias ópticas, a primeira filosófica, a segunda anatômica e a terceira matemática. A intenção é mapear a situação da óptica no que concerne à função do olho humano antes dos trabalhos revolucionários de Kepler nessa área no início do século xvir.
\end{abstract}

Palavras-Ghave • Óptica. Visão. Câmara escura. Anatomia. Perspectiva. Euclides. Alhazen. Kepler.

\section{INTRODUÇÃO}

O objetivo central deste texto é apresentar os principais aspectos do papel do olho humano, seu funcionamento e sua importância, para a ciência da óptica no final do século XVI e início do século xvII. ${ }^{1}$ A apresentação se restringe ao modo pelo qual se entendia

\footnotetext{
1 A história da óptica dos gregos antigos até o início do século xvıı é muito complexa. Não iremos reproduzi-la, por exceder em muito os objetivos deste artigo. Salientamos apenas os aspectos centrais, sem detalhar os argumentos, acerca do problema de como se produz a visão e a relação entre anatomia, filosofia e matemática. Para o leitor interessado na história da óptica até o início do século xvıı, sugerimos em especial três autores, Crombie, Lindberg e Ronchi. Lindberg (1976) é uma história da óptica desse período com boa apresentação e com um enfoque interpretativo das três tradições de pesquisa, filosófica, médica e matemática, surgidas na Grécia antiga; em Lindberg (1971), há uma apresentação de Al-Kind; em Lindberg (1967), é analisada a recepção e a importância de Alhazen para o ocidente. Crombie $(1967,1990$ e 1991) mostra o desenvolvimento da óptica no mundo grego, medieval e renascentista, comparando-o com o desenvolvimento no século xviı; em Crombie (1987) temos um panorama da óptica na Idade Média. Ronchi (1952 e 1959) são obras clássicas sobre o período. Outros autores merecem destaque: Cohen \& Drabkin (1948) pelos textos de autores antigos, especialmente de Euclides e de Ptolomeu; Castiglioni (1941) e Singer (1996) fazem apresentações históricas da anatomia; Smith (1988) discute a percepção visual em Ptolomeu; Unguru (1972) discute a matemática de Vitélio; Hatfield \& Epstein (1979) discutem Ptolomeu e Alhazen; e Pirenne (1952) é uma boa introdução ao estudo da teoria da perspectiva de Leonardo da Vinci.
} 
a formação da imagem dos objetos vistos pelo olho humano. Nossa intenção com este artigo é simples: delimitar a situação desse campo de estudos ópticos no período em questão para podermos discutir, num texto futuro, a importância de Kepler para a óptica moderna.

O papel e a função do olho humano apresentam, quando analisados da perspectiva da história da óptica, uma situação complexa. Um fenômeno óptico contém pelo menos três constituintes: um objeto que é visto, um olho que vê esse objeto, e um meio que está entre eles. Sendo assim, pode-se considerar que um fenômeno óptico é tanto um fenômeno físico, pois há uma relação entre o objeto visto e o olho que o vê com interposição do meio e da luz; quanto fisiológico e anatômico, pois o objeto visto é, de alguma forma, percebido pelo olho de acordo com seus mecanismos internos (anatomia e fisiologia); e possui também um componente psicológico, pois há uma representação do objeto visto por quem o observa. Além disso, podemos analisar um fenômeno óptico de acordo com a geometria, decompondo tal fenômeno em linhas, ângulos e curvas. Grosso modo, como se classifica o fenômeno óptico? Físico, fisiológico, geométrico ou psicológico? Ou todos ao mesmo tempo ${ }^{2}{ }^{2}$ Esse foi um dos problemas enfrentados pelos primeiros estudiosos; e, dos estudos nesses vários campos, surgiram teorias e argumentos que levaram a um desenvolvimento dessa ciência nos períodos subseqüentes.

A óptica do final do século xvi é a conseqüência dos diversos desenvolvimentos pelos quais ela passou desde os gregos até esse período. A óptica da época de Kepler resultou fundamentalmente de dois períodos, de duas grandes épocas de estudos e mudanças: uma se deu na Grécia antiga, quando a óptica se estabeleceu como disciplina científica, pois as bases, tanto matemáticas, principalmente com Euclides e Ptolomeu, quanto fisiológicas e anatômicas, expressas admiravelmente por Galeno, foram pela primeira vez na história dessa ciência organizadas em corpos teóricos bem definidos; aliado a isso, encontram-se concepções filosóficas que influenciaram tais teorias, provindas basicamente da filosofia dos atomistas, de Platão e de Aristóteles.

\footnotetext{
2 No prefácio de sua obra Optics: the science of vision, Ronchi alerta para as dificuldades históricas que surgem quando procuramos uma correta delimitação dos estudos ópticos. O fato da óptica ser hoje em dia um ramo admitido da física pode enganar-nos obscurecendo as diferentes possibilidades de classificá-la. Além da óptica física, temos a óptica fisiológica, psicológica, geométrica, técnica, óptica de ondas etc. Também são de interesse as diversas aplicações que a óptica tem: na física, na oftalmologia, na astronomia, na matemática etc. Assim, Ronchi admite que "quanto mais eu procurava delimitar o significado do termo 'óptica' e definir o seu conteúdo, mais isso me escapava. Sempre foi comum considerar característico da óptica ela ser um ramo da física, aplicada a suas construções puramente matemáticas: a óptica geométrica e a óptica de ondas; e isso mostra que podemos ter perdido a essência da óptica física" (Ronchi, 1959, p. 6).
} 
O outro período remonta ao século xiII, destacando-se os nomes de Alhazem, Roger Bacon e Vitélio, que desenvolveram ou mudaram alguns dos enfoques centrais dos gregos antigos. Após os trabalhos desses ópticos, ocorreu um grande desenvolvimento nos campos da anatomia, no século xvI, e da perspectiva, nos séculos xv e xvI. Nesse sentido, a compreensão do papel da óptica nos finais do século xvi e início do século xvII necessita de uma apresentação desses dois períodos de sua história.

\section{As BASEs da Óptica NA ANTiguidade}

A Grécia antiga forneceu as bases para a análise da óptica. Um fenômeno óptico podia ser entendido segundo três tradições de pesquisa: ${ }^{3}$ uma filosófica ou física, na qual se consideravam principalmente as questões epistemológicas; uma médica, voltada para o estudo anatômico e fisiológico do olho; e uma tradição matemática, preocupada com a explicação geométrica da percepção espacial. Essas três maneiras de entendimento da óptica formaram a base para todas as teorias criadas até o início do século xvir. Essa situação é resumida por Lindberg:

Existiram três meios para classificar por completo o pensamento acerca da óptica para os gregos. A despeito de qualquer justaposição, essas três tradições parecem conter o grande corpo da óptica grega: uma tradição médica, concernente primariamente com a anatomia e a fisiologia do olho, e o tratamento das doenças do olho; uma tradição física ou filosófica, voltada para as questões epistemológicas, psicológicas e de causalidade física; e uma tradição matemática, dirigida principalmente para uma explicação geométrica da percepção do espaço. Posteriormente, quando a civilização grega entrou em declínio, essas mesmas três tradições foram transmitidas para o Islã e o cristianismo latino, que abasteceram tanto com estruturas quanto com materiais a ciência da óptica medieval. Portanto, para se compreender as teorias da visão da Idade Média e do Renascimento, devemos referir ao pensamento grego (Lindberg, 1976, p. 1).

3 Utilizamos essa idéia de três tradições de pesquisa tal como foi originariamente sugerida por Lindberg (1976). Alguns autores, tal como Crombie (1967, 1990, 1991), não vêem três tradições distintas, mas apenas modos diferentes de considerar um fenômeno óptico, sendo a anatomia e a matemática independentes, e as concepções filosóficas embutidas em uma ou outra dessas concepções. A noção de "tradição de pesquisa" parece importante porque auxilia a entender que um fenômeno óptico, para ser compreendido em todas as suas características, necessita de uma espécie de decomposição nos vários níveis que o conhecimento humano pode usar para obter uma explicação e descrição satisfatória do mesmo. 
Passaremos a apresentar abaixo algumas das características gerais dessas três tradições e a importância das mesmas para a formulação de teorias ópticas.

\subsection{A TRADIÇÃo Filosófica}

A preocupação básica dos filósofos gregos foi a de elaborar explicações sobre como ocorre a visão de acordo com a perspectiva física, isto é, qual é a relação física entre o objeto visto e o órgão dos sentidos humanos que o vê, o olho, tendo como adicionais o meio que os contêm e a luz que atravessa todo esse meio. Duas interpretações foram predominantes: a teoria da intromissão (ou recepção) originária dos atomistas, e a teoria da emissão, proposta por Platão e Aristóteles.

A suposição básica da teoria da intromissão é a de que o próprio objeto visto emite raios visuais que atingem o olho que vê esse objeto e, durante o trajeto da imagem até o olho, ocorre uma série de simulacros (eidola) do objeto visto; em outros termos, a teoria da intromissão admite que qualquer objeto que é visto, uma mesa, por exemplo, é o responsável, mediante a ação da luz que ilumina esse objeto, pela emissão de simulacros dele próprio que atingem o olho humano e, após um processo anatômico e fisiológico no olho, esses simulacros chegam ao cérebro humano, formando a imagem, ou seja, a representação do objeto no cérebro. Diversas conseqüências e críticas foram extraídas dessa interpretação, sendo a mais importante a "diminuição" da imagem do objeto no processo de formação dos simulacros (cf. Lindberg, 1976, p. 2) e, assim, o olho recebe uma imagem diminuída do próprio objeto, pois os simulacros, durante o percurso através do meio, vão perdendo a sua originalidade e enfranquecendo-se.

Ao contrário dessa teoria da intromissão, Platão (4 $27-347$ a.G.), seguindo tanto a escola pitagórica, especialmente Alcmaeon de Crotona, quanto a deEmpédocles, tomou como base para a sua teoria da visão a suposição de que é o próprio olho que emite os raios visuais que atingem o objeto formando a sua imagem. Admite-se, segundo essa teoria, que o fogo é o principal elemento para conduzir os raios visuais emitidos pelo olho; nesse sentido, essa teoria foi denominada de teoria da emissão ou teoria do fogo intra-ocular. Porém, Platão, no Timeu ( 45 d), ao escrever "Quando toda a corrente da visão, submetida às mesmas afecções pela similitude de suas partes, toca em algum objeto ou é por ele tocada, transmite todos os movimentos através do corpo até a alma, produzindo em nós a sensação que nos leva a dizer que vemos", concebe duas emanações: uma provinda do olho e outra que tem como origem o objeto visto, de modo que essas duas emanações formam a imagem do objeto visto no meio entre elas. Lindberg sintetiza a ação dessas duas emissões que formam a visão do seguinte modo: 
A tensão dessa passagem [de Platão] não está na emissão tanto do olho quanto do objeto da visão, mas na formação de um corpo, mediante a união dos raios visuais e da luz do dia, a qual serve como um material intermediário entre o objeto visível e o olho. [...] contudo, o que se deve ter em mente é que a visão não resulta da união da emanação do objeto visível com a emanação do olho, mas do encontro da emanação do objeto com o "corpo homogêneo singular" formado pela união entre a emanação ocular e a luz do dia. Através desse encontro, os movimentos são transmitidos para a alma, produzindo, desse modo, a sensação (Lindberg, 1976, p. $5^{-6)}$.

O meio e a luz tornam-se, portanto, os principais fatores para que ocorra a visão, que, conjuntamente com a emissão de raios visuais pelo observador, formam o objeto visto. Aristóteles (384-322 a.C.), de sua parte, dá maior importância que Platão ao meio e à luz. Dando lugar central a esta última, Aristóteles desenvolve uma explicação de como ocorre a visão através do meio. Para ele, a luz não é um corpo ou um substrato, mas funciona diretamente na atualização do meio transparente, apresentando ao observador as figuras do objeto visto, como escreve Lindberg:

Luz, para Aristóteles, não é algo auto-existente, mas o estado de algo distinto, não uma substância, mas a atualidade de um meio transparente [...], luz é a atualização dessa transparência, o empreendimento do estado no qual a transparência não é mais potencial, mas atual, de maneira que os objetos separados do observador pelo meio tornam-se visíveis. Semelhante atualização ocorre na presença do fogo ou de algum outro corpo luminoso [...]; o verdadeiro objeto da visão, entretanto, não é a luz, mas a cor. A cor é uma característica da superfície dos corpos, os quais têm a capacidade de produzir futuras mudanças qualitativas no transparente atual. Assim, o transparente deve primeiro ser levado para a atualidade através da presença do corpo luminoso. O transparente atual é então movido pelo corpo colorido para outra mudança qualitativa (uma secunda atualidade), e a última é transmitida para o observador, o qual percebe a cor (Lindberg, 1976, p. 8).

O ponto básico dessa teoria é a atualização do meio transparente pela luz, que permite ao observador ver as figuras dos objetos, assim como as suas cores. A teoria original da emissão é, dessa maneira, alterada por Aristóteles, que não dá muita importância para a emissão dos raios visuais pelo olho do observador, mas concentra o forte de sua argumentação no meio que contém a luz e a atualização da forma dos objetos. Tanto o meio quanto o olho formam um conjunto, um mecanismo, no qual ocorrem as 
interações entre ambos e, dessas interações, a figura do objeto visto é conduzida para o cérebro do observador.

De qualquer modo, a teoria da emissão aproxima-se mais do que a teoria da intromissão dos aspectos subjetivos, isto é, a teoria da emissão, seja na formulação platônica (concernente à alma que recebe informações), seja na formulação aristotélica (que valoriza o meio atualizado), necessita de um componente psicológico que recebe os movimentos de transmissão das imagens.

\subsection{A tradição ANATÔMica E Fisiológica}

A prática de dissecações na medicina grega antiga surge inicialmente com Alcmeon de Crotona por volta de 500 a. G., que desenvolveu os estudos anatômicos (cf. Castiglioni, 1941, p. 158). Alcmeon também foi o primeiro médico que tratou da anatomia do olho; ele estudou o nervo óptico e admitiu que existem três substâncias responsáveis pela formação da visão: a luz externa, o fogo interno do olho e os humores como meios de

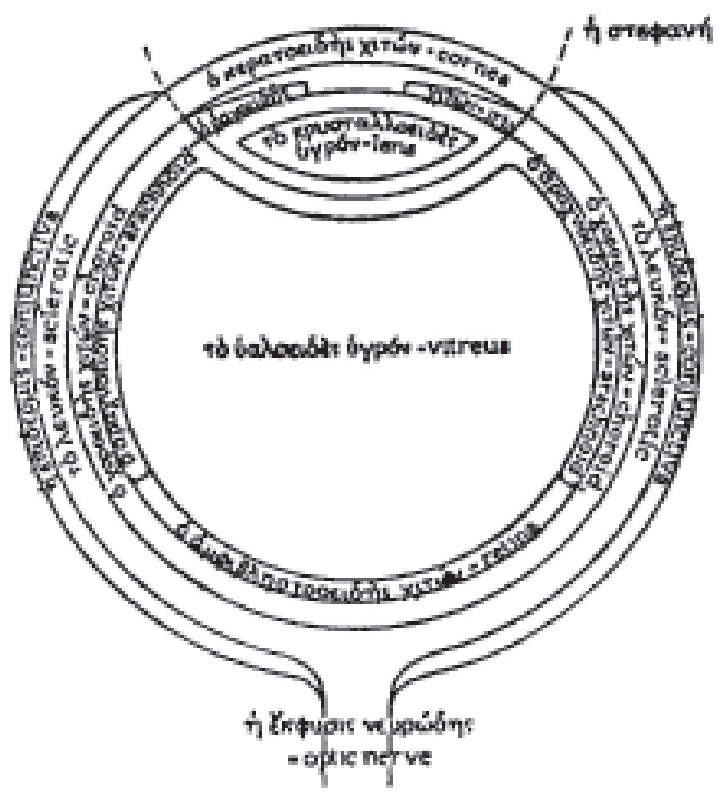

Figura 1. Descrição do olho humano atribuída a Rufo de Éfeso (ca. 5 o d.C.). A figura expressa uma das primeiras tentativas de decomposição do olho em suas partes constituintes. Apesar das modificações posteriores, a divisão do olho em esclerótica, coróide, conjuntiva etc continuará servindo de base para as descrições anatômicas. transmissão (cf. Castigloni, 19411, p. 159). Um grande desenvolvimento para a anatomia foi dado pela escola hipocrática; contudo, os seus conhecimentos foram adquiridos fundamentalmente através de dissecações de animais, e de anatomia comparada.

Apesar disso, os gregos tiveram uma certa tradição de estudos anatômicos e fisiológicos do olho; os gregos representaram a estrutura e as partes do olho, baseadas em túnicas, humores cristalinos, aquoso e vítreo, nervo óptico, córnea, íris etc, conforme podemos notar na figura 1 , atribuída a Rufo de Éfeso (ca. 5 o d.C.), a qual é uma das primeiras representações anatômicas do olho.

Nessa figura de Rufo, temos a representação da estrutura externa e interna do olho. Nela podemos notar especialmente a córnea, a lente e o vítreo; vemos também três túnicas: a conjuntiva, a esclerótica e a coróide; além disso, temos o olho unido ao 
nervo óptico. Essa descrição do olho dada por Rufo de Éfeso sofrerá muitas alterações ao longo da história da anatomia, mas a estrutura anatômica básica do olho já se encontra esboçada nela.

O maior representante da tradição anatômica e fisiológica do olho na Antiguidade romana foi Galeno de Pérgamo (129-199). Seguindo a teoria da emissão, juntamente com a concepção estóica do pneuma óptico, ${ }^{4}$ Galeno elaborou uma explicação de como se dá a visão, embora não considere que o olho emite um pneuma, mas que o próprio ar é o instrumento que leva o olho a ver um objeto iluminado pela luz solar. Essa concepção de Galeno é devedora de Aristóteles, pois ela utiliza a noção de meio transparente que atualiza as formas dos objetos vistos pela ação da luz. Contudo, mais importante que essa explicação filosófica de como se dá a visão é a descrição anatômica e fisiológica que Galeno apresenta para o olho humano.

Galeno, em Sobre o uso completo das partes do corpo, foi o primeiro a atribuir ao humor cristalino a função de principal instrumento da visão, justamente por ele ser o último receptor sensitivo, conforme ele escreve:

O próprio humor cristalino é o principal instrumento da visão, um fato claramente provado por aquilo que os físicos chamam de catarata, que se localiza entre o humor cristalino e a córnea (Galeno apud Lindberg, 1976, p. 11).

Para Galeno, quando um homem sofre de catarata, esta impede que o objeto seja percebido pelo olho desse homem, isto é, quando a catarata encobre o humor cristalino, o homem deixa de ver. Galeno inferiu disso que é o humor cristalino a parte do olho responsável pela visão; sendo assim, é no humor cristalino que as imagens são formadas. Essa função atribuída ao humor cristalino prevalecerá por toda a Idade Média, só sendo rompida por Kepler que, seguindo a anatomia de Felix Plater, atribuirá à retina o papel de principal responsável anatômico pela formação das imagens no olho humano.

A tradição médica grega, portanto, procurou descrever as partes que compõem o olho, fornecendo um certo mapa dessas partes e uma teoria de como elas podem se relacionar e formar a visão. Imbuídas de concepções filosóficas e, como em Galeno, matemáticas (porque ele aceita o cone visual euclidiano como uma descrição geométrica a respeito da maneira pela qual a luz age nas partes do olho), as explicações anatômicas e fisiológicas antigas estipularam as bases para os futuros estudos sobre o funcionamento do olho no ato da visão.

4 Os estóicos entendiam o pneuma óptico como um agente ativo composto da mistura de ar e de fogo que, transmitido pelo olho, excita o ar que lhe é adjacente, levando esse ar a um estado de tensão que, quando em contato com a luz solar, leva o olho a ver um determinado objeto (cf. Lindberg, 1976, p. 9). 


\subsection{A tradiçÃo matemática}

A tradição matemática foi a que obteve o maior desenvolvimento na óptica durante a antiguidade grega. Ela representa a tentativa de geometrizar o que se visualiza pelo uso de retas e ângulos num espaço tridimensional. A tradição geométrica grega para a ciência da óptica está ligada ao mesmo tipo de compromisso que a geometria tem com a astronomia, isto é, na astronomia, os gregos reduziam os fenômenos celestes às propriedades da esfera e dos seus raios, de modo a terem uma linguagem que permitisse representar os movimentos do Sol, da Lua e dos planetas. Por sua vez, na óptica os gregos reduziam os fenômenos ópticos às propriedades dos ângulos e retas (cf. Crombie, 1990, p. 606). Em nenhuma outra civilização antiga parece ocorrer um tal compromisso: o de entender os fenômenos físicos, como os ópticos, mediante uma aplicação matemática que visa a sistematização do conhecimento desses fenômenos. Assim, os matemáticos gregos conseguiram dar à óptica um desenvolvimento quase tão significativo quanto o da astronomia, da mecânica e da própria matemática nessa civilização (cf. Crombie, 1987, p. 97).

Os maiores expoentes da tradição matemática da óptica grega foram Euclides e Ptolomeu. Ao primeiro devemos a teoria do cone geométrico, no qual o olho humano torna-se o ápice do cone e o objeto visto a sua base. Ao segundo, uma aplicação matemática que considera os aspectos físicos dos fenômenos ópticos.

A importância de Euclides (século ııı a.C.) para a tradição matemática da óptica é fundamental, sendo reconhecido como o fundador dessa tradição. Pode-se dizer que ele "criou a ciência da óptica geométrica e perspectiva ao tomar o olho como o ponto de origem das linhas de visão, das quais ele postulou as propriedades essenciais" (Crombie, 1990, p. 606-7). Tais propriedades são os sete postulados de Euclides contidos em sua Óptica, que são:

(1) que os raios retilíneos procedentes do olho divergem indefinidamente;

(2) que a figura contida por um grupo de raios visuais é um cone, do qual o vértice localiza-se no olho e a base na superfície do objeto visto;

(3) que as coisas que são vistas sob os raios visuais diminuem e as coisas que não são vistas sob os raios visuais não diminuem;

(4) que as coisas vistas sob um ângulo grande parecem largas e aquelas sob um ângulo pequeno parecem pequenas, e aquelas sob ângulos iguais parecem iguais;

(5) que as coisas vistas sob um ângulo visual amplo parecem amplas e as coisas vistas sob um ângulo visual reduzido parecem reduzidas; 
(6) que, similarmente, as coisas vistas sob raios mais afastados para a direita parecem mais afastadas para a direita e coisas vistas sob raios mais afastados para a esquerda parecem mais afastadas para a esquerda;

(7) que as coisas vistas sob ângulos maiores são vistas mais claramente (Euclides apud Cohen \& Drabkin, 1948, p. 257-8).

Esses postulados representam a primeira tentativa de entender os fenômenos ópticos de uma perspectiva matemática. Com eles, Euclides pretende construir uma descrição dos fenômenos ópticos de acordo com os modos geométricos espaciais (direita, esquerda, alto, baixo, afastado e perto) pelos quais um objeto pode ser visto pelo observador, isto é, Euclides concebe o espaço visual do olho e extrai as relações possíveis, expressando-as em termos de retas e ângulos; assim, o ângulo formado pelo objeto e o observador determina as características que são vistas. Por exemplo, se o ângulo que subentende o olho e o objeto é alto (podemos entender alto como sendo um ângulo que forma mais de $45^{\circ}$ entre o centro do olho e o objeto), pelo quinto postulado, o objeto parecerá alto. Pelo primeiro postulado, Euclides reduz os raios visuais a retas, de modo que estudamos todos os raios visuais emitidos pelo olho como retas que formam ângulos. Mas o mais importante é o que é dado pelo segundo postulado, relativo ao cone visual, que pode ser apreciado nas figuras abaixo.

As duas figuras mostram o cone visual euclidiano, que expressa o princípio geométrico básico da pirâmide visual compreendida pelo olho e objeto. O olho é o vértice do cone e o objeto visto forma a base do mesmo. O interessante em Euclides é que existe uma teoria da perspectiva subentendida em sua óptica geométrica. O cone visual é um diagrama que permite o estudo de algumas relações envolvidas em um fenômeno óptico. Ao reduzir o campo de visão ao que o cone delimita, sendo o centro desse campo o próprio olho, pode-se obter informações sobre a distância entre o observador e o objeto visto por meio das relações entre retas e ângulos.

O cone visual euclidiano foi a teoria óptica que mais se difundiu durante a Idade Média e o Renascimento. Todos os grandes ópticos subseqüentes a Euclides, incluindo Ptolomeu, AlKind, Alhazen, Roger Bacon, Pechan e Vitélio, entre os mais relevantes, aceitaram esse paradigma geométrico.

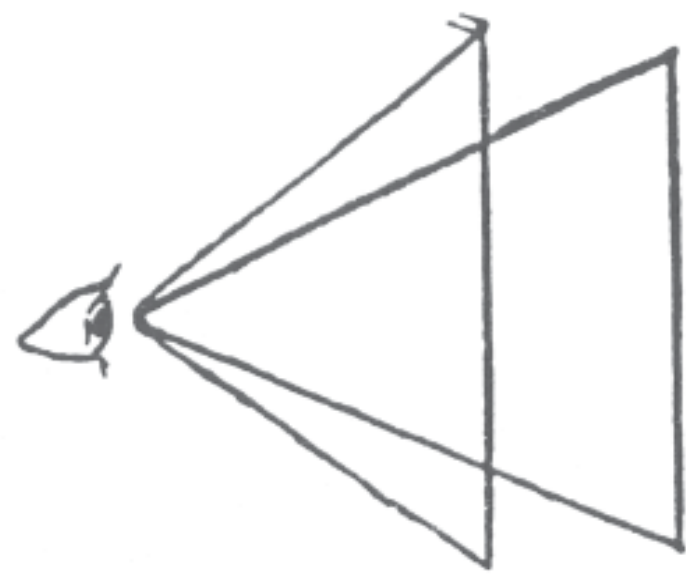

Figura 2. A teoria do cone visual de Euclides, na qual o olho emite os raios visuais que atingem o objeto visto (teoria da emissão). O olho é o ápice do cone visual e o objeto visto é a sua base. 


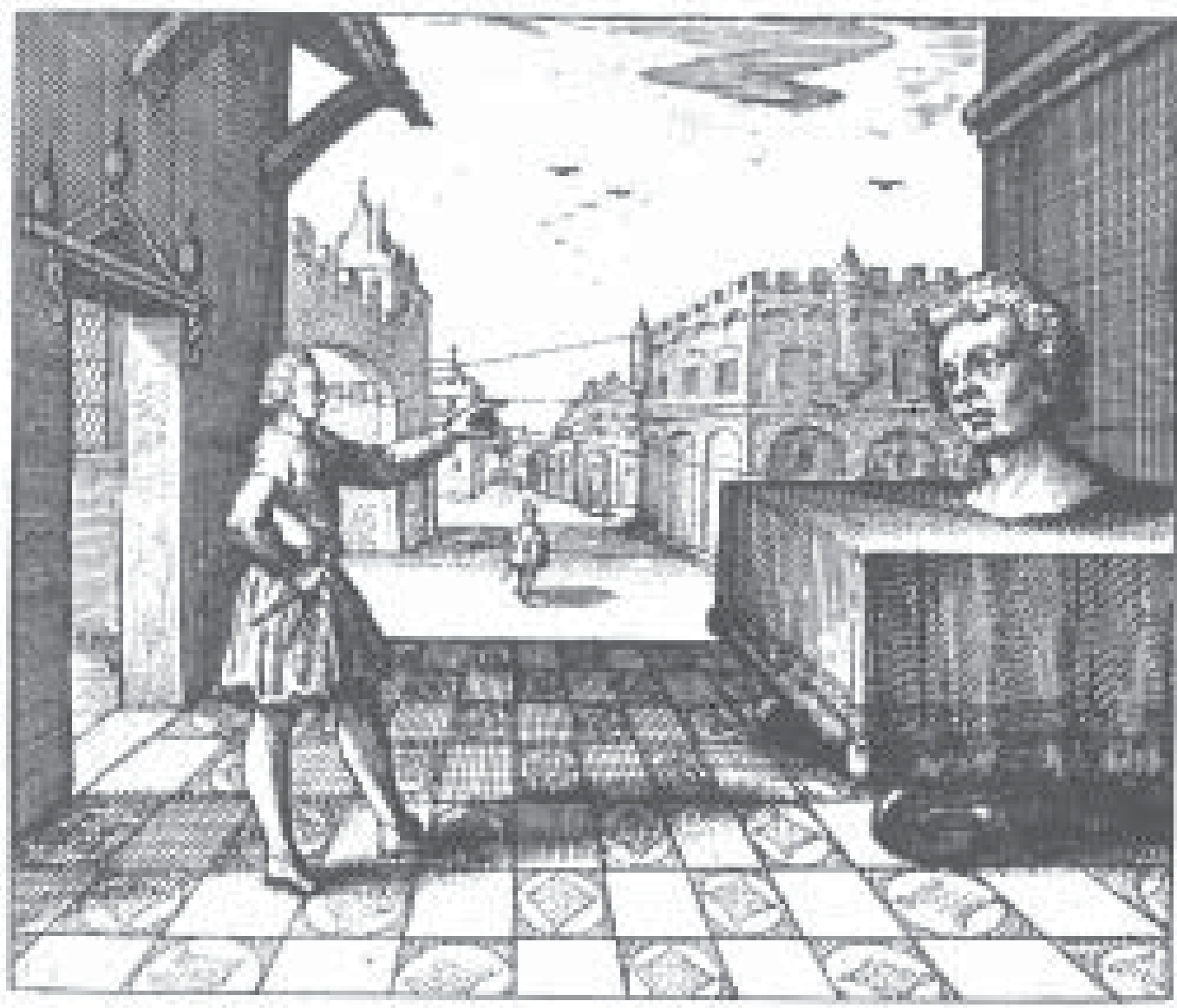

Figura 3. A visão para Euclides. Esta representação aparece na obra de Robert Flud que trata do microcosmo humano, publicada no ano de 1618 . 0 homem, que está à esquerda, emite os raios visuais que atingem o busto à direita; as linhas tracejadas que estão entre o olho e a estátua são os raios visuais euclidianos.

A teoria do cone visual euclidiano perdurou até Kepler, quando este inverte o cone - o vértice passa a estar em cada ponto iluminado do objeto visto e a base no próprio olho. O fundamental para a história da óptica é que a teoria euclidiana do cone visual "restringiu" o entendimento do funcionamento do olho humano. A teoria do cone visual euclidiano foi feita admitindo-se que o que o olho vê é expressão da realidade do mundo externo. $O$ fato do vértice do cone estar no olho implica que o olho capta as informações de um campo visual específico. Aqui está envolvida a concepção filosófica de Euclides. Ele seguiu a teoria da emissão, admitindo que é o olho humano que emite raios que chegam ao objeto, e esses raios voltam ao observador em forma de dados, de imagens que são processadas no olho e passam, a seguir, para o cérebro do 
observador. Com isso, a geometria do cone euclidiano funciona para uma concepção de visão ativa. Os desenvolvimentos na óptica do século xvıı, que terão como base a inversão do cone visual feita por Kepler, conduzirão para uma "desmistificação" do papel do olho como agente ativo; o olho será agora entendido como o receptáculo de informações provindas do objeto, no qual cada ponto - cada vértice de um cone visual - será representado na pupila do olho, sofrendo alterações dentro do mesmo até representar uma imagem do objeto.

Como foi dito acima, a tradição geométrica da óptica na Antiguidade obteve resultados que a colocam no mesmo patamar que a astronomia. Um dos principais ganhos nessa ciência foi a formulação correta da lei da reflexão da luz, para a qual o ângulo de reflexão dos raios de luz sobre uma superfície é igual ao ângulo de incidência. Tal lei fora descoberta já na Antiguidade, por Euclides, e foi aperfeiçoada por Alhazen que afirma que o raio incidente, o raio refletido e a normal estão todos no mesmo plano. $\mathrm{O}$ estudo da reflexão da luz em espelhos foi denominado pelos gregos antigos de catóptrica . O fenômeno da reflexão era melhor conhecido do que o da refração na época de Kepler.

Ptolomeu (100-170), ao contrário de Euclides, foi um matemático que se preocupou com algumas questões físicas. 5 Admitindo também a teoria da emissão, Ptolomeu tratou, principalmente, da questão da luz e das cores. Para Ptolomeu, "a visão é o resultado da interação da radiação visual e das cores, assistidas por iluminação externa" (Lindberg, 1976, p. 16).

No campo da perspectiva, Ptolomeu desenvolveu alguns teoremas; entre os mais importantes, está o teorema 16 que se encontra no livro in da Óptica, segundo o qual "aquilo que está sobre o eixo mostra-se mais claro que aquilo que é observado sobre os lados, através dos raios laterais" (Ptolomeu apud Lindberg, 1976, p. 17).

Além disso, cabe destacar que Ptolomeu realizou experimentos no campo da óptica geométrica, principalmente com relação às mudanças da ação da luz em meios heterogêneos, tais como o ar e a água, esboçando, mas não obtendo, a lei da refração da luz. Ptolomeu mediu os ângulos de refração dos raios ao passarem do ar para a água e para o vidro. Dessas medições, ele observou que os ângulos formados por raios que passam de um meio para outro sempre são menores que os ângulos de incidência, mas

5 Existe uma controvérsia acerca do papel de Ptolomeu no campo da óptica que é análoga à controvérsia do seu papel no campo da astronomia. Comumente, admite-se que Ptolomeu importou princípios físicos dos filósofos naturais para basear suas teorias astronômicas; nesse sentido, o primeiro livro do Almagesto pode ser visto como cosmológico e os 12 restantes como matemáticos. Na óptica, alguns autores como Lindberg (1976) tratam a questão da mesma forma que na astronomia, isto é, Ptolomeu importou de Aristóteles os princípios físicos necessários para a sua óptica matemática. Porém, outros comentadores, como Smith (1988), rejeitam essa interpretação, argumentando que Ptolomeu não se restringiu à tradição matemática, mas trabalhou com a natureza da luz, por exemplo. Seja como for, para os nossos propósitos neste texto, classificamos Ptolomeu como um representante da tradição matemática. 
supôs erroneamente que isso sempre ocorria em proporção constante (cf. Crombie, 1987, p. 97). Mas Ptolomeu não chegou à lei da refração; esta só foi descoberta por Descartes e Snell no século xviı, cada um independentemente. O estudo da refração foi designado pelos gregos antigos de dióptrica.

Em suma, as três tradições gregas sobre o estudo dos fenômenos ópticos - filosófica, médica e matemática - forneceram cada uma contribuições para a formulação das teorias ópticas subseqüentes. Pode-se dizer que os gregos lançaram as bases dessa ciência. As teorias elaboradas, tratando especialmente ou da intromissão ou da emissão dos raios visuais, influenciaram os estudiosos islâmicos e latinos entre os séculos IX e XIII; os estudos anatômicos de Galeno formaram a base para os anatomistas dos séculos subseqüentes, só sendo superados nos séculos xvi e xvII; e, finalmente, as teorias da tradição matemática, em especial a teoria do cone visual euclidiano, mantiveram-se, mesmo que com algumas alterações, como um dos principais paradigmas dos ópticos matemáticos da Idade Média e do Renascimento. Assim, os trabalhos que se seguiram aos dos gregos tiveram, de uma forma positiva ou negativa, influência desses três modos de abordar a óptica.

\section{A óptica do SÉculo XIII}

O desenvolvimento da óptica depois dos gregos teve como centro a cultura árabe. As diversas traduções de trabalhos filosóficos, médicos e matemáticos gregos feitas pelos árabes permitiram um maior aprofundamento das pesquisas nas ciências e na filosofia com relação àquelas feitas no ocidente entre os séculos IX a XIII. Os árabes continuaram a tradição grega na óptica, nas suas perspectivas matemática, médica e filosófica, desenvolvendo alguns conteúdos sem, contudo, mudá-los em seus aspectos centrais. $\mathrm{O}$ primeiro nome significativo da cultura árabe é Al-Kind, nascido provavelmente no final do século viı e falecido em 866. Al-Kind se preocupou especificamente com a óptica matemática, tratando de algumas lacunas contidas na Óptica de Euclides. Na sua obra De aspectibus (Sobre as aparências), Al-Kind mostra que as linhas retas que formam o cone visual não são emitidas por raios visuais, mas por raios luminosos; dessa forma, Al-Kind muda o enfoque para os "campos visuais", argumentando, principalmente, que a visão, para ser compreendida pela perspectiva matemática, não se dá pela emissão de raios unidimensionais, mas dentro de um campo de propagação (cf. Lindberg, 1976, p. 26).

No campo da anatomia e da fisiologia, Hunain Ibn Ishaq (?-877), conhecido no ocidente como Johanitus, desenvolveu a anatomia do olho a partir dos ensinamentos da escola galênica. Para Johanitus, o humor cristalino é o responsável pela formação da 
imagem dos objetos vistos, e esse humor é incolor, transparente, luminoso e redondo; nele se formam as imagens entendidas como "espíritos visuais" e que vão para as outras partes do olho até essas imagens chegarem ao nervo óptico e seguirem para o cérebro. A noção de espíritos visuais servirá para explicar como as imagens visuais são transferidas para as várias camadas e partes do olho. Ela será sua utilizada até o século xvıI, quando Kepler a abolirá, substituindo-a pela noção de "imagem refratada na retina”. A anatomia do olho para Johanitus é representada na figura abaixo.

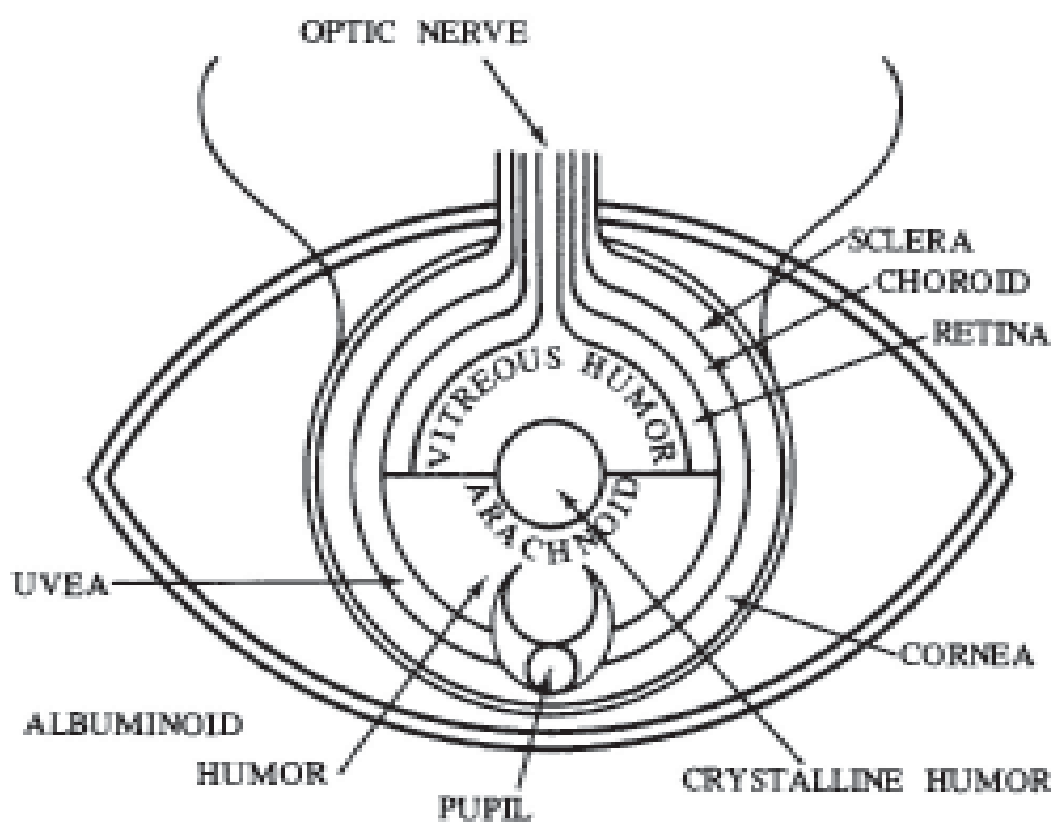

Figura 4. $\mathrm{O}$ olho para Johanitus, anatomista árabe seguidor de Galeno que viveu no século Ix de nossa era e que se dedicou à compreensão da estrutura do olho. Na figura, o olho compõe-se de humores, túnicas e a formação de imagens se dá no cristalino; em seguida, elas dirigirem-se ao cérebro através do nervo óptico.

Podemos notar o humor cristalino acima da pupila, rodeado por uma camada chamada de aracnóide; antes do humor cristalino, vem o humor vítreo, contendo três túnicas: a retina, a coróide, ou secundina, e a esclerótica (córnea opaca); a função do humor vítreo é alimentar o humor cristalino com sangue; entre o humor cristalino e o vítreo existe o humor aquoso (albuminoso). A imagem (espírito visual) passa do humor vítreo para o humor cristalino e, a seguir, para o nervo óptico.

Essas tradições matemáticas e anatômicas apontadas tiveram como suporte o arcabouço filosófico vindo dos gregos, isto é, as teorias da intromissão ou da emissão. Diversos são os autores que defenderam uma ou outra teoria, dos quais não vamos 
tratar aqui. ${ }^{6} \mathrm{O}$ importante é que os autores trabalharam dentro dos paradigmas da emissão, como Al-Kind, ou da intromissão, como Alhazen, do qual falaremos abaixo. E, mais importante ainda, foram as discussões sobre as inter-relações entre os estudos anatômicos e matemáticos. No mundo árabe desse período, as orientações filosóficas e médicas de Aristóteles e Galeno conduziram a um certo afastamento da tradição euclidiana. Desse modo, os pensadores árabes podiam conceber um fenômeno ou como de cunho eminentemente geométrico, no qual se fazia a análise dos seus componentes, entendendo-os como retas e ângulos, ou como de cunho eminentemente anatômico, mas sem relacionar uma tradição com a outra, tal como é resumido abaixo:

A orientação não matemática das teorias galênicas e aristotélicas sobre a visão devem ser enfatizadas. Nelas não encontramos análise geométrica significativa, nem ciência da catóptrica ou da dióptrica, e tampouco uma menção da propagação retilínea da luz. No lugar das realizações de Euclides e Ptolomeu, encontramos uma discussão da anatomia ocular e da fisiologia, e uma análise dos modos físicos possíveis de radiação. Somos aqui capazes de perceber o abismo que separa as várias abordagens do problema da visão. A teoria euclidiana por um lado e as teorias aristotélica e galênica por outro são simplesmente incomensuráveis, porque elas têm objetivos fundamentalmente diferentes. Foi o contemporâneo de Avicena, Alhazen, que conseguiu demonstrar como a anatômico, o físico e o matemático podem ser integrados em uma única teoria da visão (Lindberg, 1976, p. 57).

Ou seja, no início do século xiır temos, na óptica, um período de tensão da anatomia e da fisiologia aristotélica-galênica com a geometria euclidiana. O interessante são os objetivos distintos de uma ou outra tradição. A tradição anatômica voltava-se para o estudo da visão, procurando uma melhor descrição da anatomia do olho, para principalmente curar doenças dos olhos; nesse sentido, como aplicar a geometria nas dissecações? Por outro lado, a tradição euclidiana era antes de tudo uma tradição matemática, para a qual o importante era entender um fenômeno óptico de acordo com a natureza dos elementos matemáticos (ângulos e retas); se é assim, em que sentido as túnicas, humores, retina etc podem ser matematizados, ou melhor, geometrizados? Estas perguntas estão nas entrelinhas das pesquisas em óptica que se seguiram, durante e após o século xiıI.

\footnotetext{
6 Destacam-se os nomes de, por exemplo, Avicena e Averroes, dois grandes aristotélicos. O leitor interessado nessas teorias e discussões poderá consultar Lindberg (1967, 1971 e 1976).
} 


\subsection{Alhazen e a óptica matemática}

O maior expoente da óptica após Euclides e Ptolomeu e antes de Kepler foi o pensador árabe Al-Haythmam (965-1039), conhecido no mundo ocidental pelo nome latinizado Alhazen. O campo de atuação de Alhazen foi muito diversificado. Além da óptica, ele trabalhou com astronomia, matemática, física, cosmologia, meteorologia, medicina, metafísica e teologia. Uma de suas principais obras sobre a óptica é o De aspectibus, também conhecido como Perspectiva, na qual apresenta e desenvolve seu pensamento a respeito de como se forma a visão.

Alhazen seguiu três pontos específicos para a elaboração da sua teoria óptica. Em primeiro lugar, considerou o olho como um instrumento mecânico qualquer, igual à câmara escura; em segundo lugar, sobre a anatomia do olho, seguiu os ensinamentos de Galeno, considerando o cristalino como o local em que as imagens se formam no ato da visão; e, em terceiro lugar, admitiu a teoria do cone visual de Euclides e a suposição de campos visuais de $\mathrm{Al}$-Kind. $\mathrm{O}$ primeiro ponto foi uma novidade para o campo da óptica; os dois últimos seguiram à risca o pano de fundo conceitual dos gregos antigos.

Acerca do entendimento do olho como um artefato mecânico, Alhazen de uma certa forma "desmistificou" o olho como um órgão vivo que produz ações, entendendo-o como um objeto de natureza passiva, que sofre as ações da luz e do meio. Alhazen parece que não desenvolveu os aspectos mais interessantes que a analogia do olho com a câmara escura pode suscitar e nem resolveu o problema básico das imagens invertidas que a câmara escura representa na sua tela de fundo. Se, por um lado, há uma identidade entre a abertura da câmara e a abertura do olho, Alhazen, contudo, não extrai disso as conseqüências mais interessantes. Apesar disso, ele restringe a quantidade de raios visuais que podem entrar pela abertura da câmara - que no olho é dada pela pupila - à relação ponto a ponto, isto é, há uma relação entre cada ponto (que se pode entender como sendo cada raio visual) provindo do objeto visto com cada ponto que se forma na pupila. Esta relação ponto a ponto segue necessariamente a teoria do cone visual euclidiano. O problema desta interpretação de Alhazen é que a correspondência ponto a ponto só se dá nas perpendiculares, isto é, no eixo do cone; para as outras posições, tal correspondência não se segue. Leonardo da Vinci, Della Porta e Kepler também entenderão o olho como análogo à câmara escura, desenvolvendo a analogia proposta por Alhazen no século XııI.

Em termos filosóficos, Alhazen segue mais a teoria democritiana da intromissão, rejeitando a explicação dada pela teoria da emissão. Como foi dito, o olho não realiza nenhuma ação, mas, ao contrário, sofre a ação da luz (cf. Lindberg, 1976, p. 63). Isso teve uma importante implicação no uso dado aos raios visuais euclidianos e campos visuais de Al-Kind. Euclides, Ptolomeu e Al-Kind seguiram a teoria platônica- 
aristotélica da emissão de raios visuais pelos olhos; de um certo modo, esses raios tinham uma espécie de existência na qual o próprio olho é o responsável físico por sua emissão. A teoria da intromissão de Alhazen retira o caráter ontológico dos raios visuais, pois eles “são meras construções geométricas, úteis para demonstrar as propriedades da visão. Eles podem servir como hipóteses matemáticas, mas não têm realidade física" (Lindberg, 1976, p. 66). A realidade física é dada pela anatomia do olho. A geometria serve para compreender as ações da luz no olho e expressá-las em termos de retas e ângulos. A teoria da intromissão após Alhazen adquiriu um status bem mais relevante que a teoria da emissão. Poucos ópticos aceitaram nos séculos seguintes que o olho emite raios visuais, ao passo que a suposição de que as imagens são formadas do objeto para o olho ganhou preponderância.

A anatomia do olho de Alhazen é galênica. Ele não fez nenhuma mudança significativa na estrutura do olho definida por Galeno, como pode se apreciar nas figuras abaixo.

As duas figuras ilustram a anatomia e o processo de visão para Alhazen. Na figura 6, vemos a mesma estrutura da figura 5 , mas com uma apresentação geométrica da ação da luz no olho. $b$ é o centro do olho, que coincide com o centro da córnea, com o do humor aquoso e com o do cristalino. Entre eles estão o centro da coróide (uvea) e da esclerótica (consolidativa). O objeto visto, em $a$ e $l$, transmite raios visuais que passam

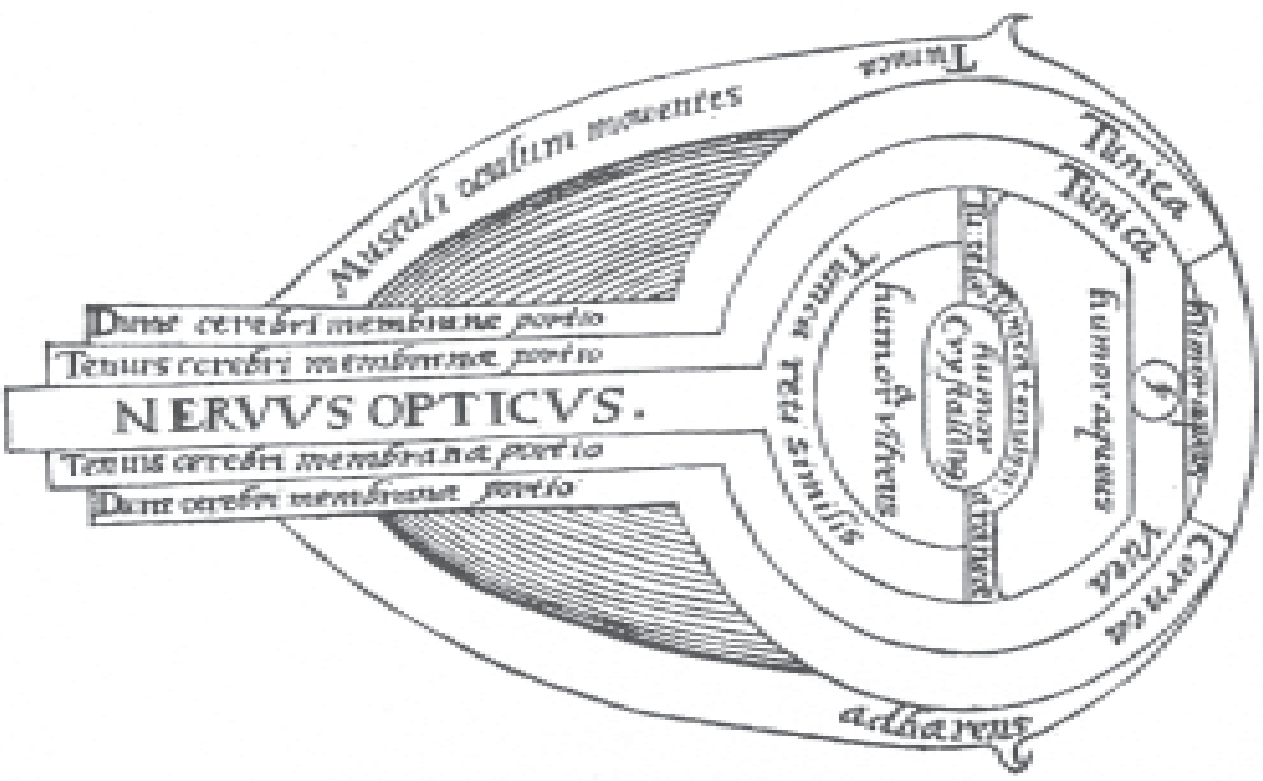

Figura 5. A anatomia do olho para Alhazen, pensador árabe, que é o principal óptico entre Ptolomeu e Kepler. A figura encontra-se na edição do De aspectibus de ${ }_{1572}$, e tornou-se uma das principais representações do olho humano até o século xvII. Todos os manuais de óptica entre os séculos xIII e xvir, incluindo Roger Bacon, Pecham e Vitélio, basearam-se na teoria de Alhazen. 
perpendicularmente pela córnea em $m$ e $o$, e chegam ao cristalino por $c$ e $d$. Até aqui, não ocorre qualquer refração; mas, após a imagem alcançar o cristalino, ela é refratada para a abertura do nervo óptico (cf. Crombie, 1990, p. 611). Nesse processo, temos a ação das emissões de raios de luz pelo objeto visto até os raios alcançarem o interior do olho, especificamente o cristalino. Há uma correspondência ponto a ponto entre as imagens no campo visual com a formação delas na superfície do olho; de modo que "das formas emitidas por cada ponto do objeto visível, as que reproduzem os pontos estimulados correspondentes do cristalino anterior reproduzem as formas de todo o objeto" (Crombie, 1990, p. 614).

Concebendo o processo óptico por esses meios, Alhazen pôde definir a ação da luz no olho e explicar a formação da visão da seguinte forma:

Essa ação que a luz efetua no cristalino é da mesma espécie que a dor [...]. A partir disso, essa sensação que ocorre no cristalino é estendida para o nervo óptico e vai para a parte anterior do cérebro, e aí reside a última sensação [...]. Esse poder apreende as coisas sensíveis, mas o olho é apenas um instrumento desse poder, porque o olho recebe as formas das coisas vistas e as envia para o último sentiente, e este apreende essas formas e apreende a partir delas as coisas visíveis que estão

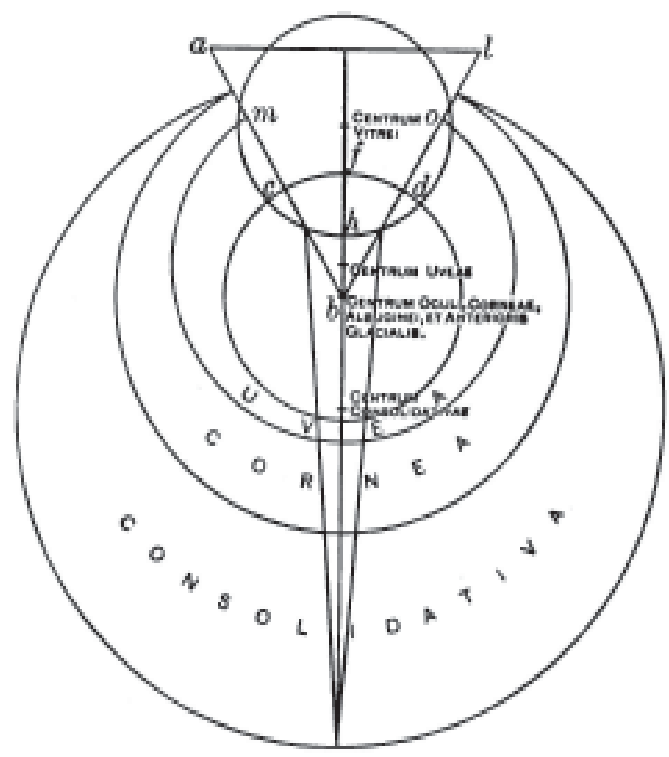

Figura 6. O processo da visão para Alhazen, tal como representado na edição de 1897 do Opus majus de Roger Bacon. A figura revela a estreita relação entre a anatomia e a geometria para Alhazen. Notamos que é no cristalino que se formam as imagens provindas dos objetos e que se pode representar geometricamente a refração das imagens visuais feitas nas partes do olho. 
nelas. A forma que está na superfície do cristalino é estendida para seu corpo, e assim para o corpo sutil que está na concavidade do nervo, até alcançar o nervo comum e, com a chegada da forma ao nervo comum, a visão é completada (Alhazen apud Crombie, 1990, p. 611).

Alguns pontos são importantes nessa passagem. Em primeiro lugar, nota-se que Alhazen considera a ação da luz no cristalino como semelhante à dor, isto é, como algo que implica alguma espécie de ação; a dor física é causada por uma ação física, um tombo, um acidente etc; a luz no cristalino, do mesmo modo, é causada pela ação física da luz. Isso é importante porque Kepler rejeitará como sendo física a ação da luz no olho, entendendo-a como a ação de uma substância imaterial. Em segundo lugar, o processo de visão não se encerra no próprio olho, mas, apesar da imagem formar-se no cristalino, ela tem uma continuidade até o cérebro; é somente no cérebro que a visão termina, implicando uma ação, no limite, psicológica. Kepler rejeitará também essa ação até o cérebro; para ele, a visão se encerra na retina, não cabendo à óptica qualquer referência às interpretações provindas do sujeito.

A importância de Alhazen para a continuidade dos estudos ópticos está, principalmente, na consideração do olho como um artefato mecânico, o que será muito explorado por Kepler no século xviı. Ademais, Alhazen foi o principal oponente da teoria da emissão, abrindo novas possibilidades de entendimento do processo de visão pela ação da luz sobre o olho. Por fim, a óptica de Alhazen caminha no sentido de uma unificação ao criar um corpo explicativo que considera a anatomia e a fisiologia como realidades físicas e as matemáticas como linguagens para representar essa realidade.

Alhazen criou, portanto, uma nova expectativa para os estudos ópticos. Os seus seguidores no ocidente, principalmente Roger Bacon, Pecham e Vitélio, dos quais falaremos mais abaixo, seguiram as suas linhas diretrizes. Mas a óptica de Alhazen, apesar de mudar em alguns aspectos a natureza da disciplina tal como era entendida pelos gregos, criou alguns problemas que só foram resolvidos por Kepler. Não somente problemas ópticos, mas de natureza filosófica, acerca justamente da compreensão da ação da luz no olho. Esses problemas podem ser resumidos em dois grupos; o primeiro, tal como expõe Lindberg, é o seguinte:

O principal concerne à natureza das entidades propagadas a partir do cristalino para o nervo comum e as suas relações com as radiações propagadas do objeto visível para o humor cristalino. [...] Se as formas da luz e e das cores são elas próprias transmitidas para o último sentiente para interpretação, qual é a função das impressões produzidas no humor cristalino, e em que sentido o cristalino é um foto-receptor? (Lindberg, 1976, p. 84). 
Esse problema envolve a questão acerca de qual é o objeto dos estudos ópticos. Esse objeto é a interpretação das imagens provindas dos raios visuais para o olho, ou a óptica se restringe apenas ao estudo da ação da luz nos constituintes internos do olho (humores, córnea, cristalino, retina etc)? A óptica de Alhazen envolve a psicologia, sendo subordinada a ela. Nela, são as interpretações subjetivas do sujeito que representam o último grau do processo de visão.

O segundo problema é técnico, mas é fundamental para a resolução do problema filosófico apontado acima. Ele pode ser apreciado segundo as palavras de Lindberg, quando ele escreve:

A pirâmide visual, a coleção de raios pelos quais a visão se realiza, consiste apenas de raios que caem perpendicularmente sobre o olho e procedem sem refração para o humor cristalino. Entretanto, na interface entre o cristalino e o humor vítreo, todos os raios da pirâmide visual são refratados de tal maneira que evitam a finalização de um vértice - todos os raios, com exceção do central, que é o eixo da pirâmide visual (Lindberg, 1976, p. 85).

Para entendermos isso, temos que lembrar que Alhazen admitiu o cone visual euclidiano, no qual o vértice está no olho e a base no objeto visto. A óptica de Alhazen satisfaz apenas os raios que entram perpendicularmente, e esses são apenas os que correspondem ao eixo central; os outros não são refratados de tal forma pelo cristalino. Esse problema envolverá uma nova concepção anatômica do olho, na qual não é no cristalino que se forma a imagem visual, mas na retina.

\subsection{A óptica no OGidente}

O ocidente latino absorveu completamente os tratados ópticos de Alhazen. Devido à grande disseminação no ocidente durante o século xıII de obras científicas árabes, juntamente com traduções árabes dos trabalhos científicos dos gregos antigos, os tratados ópticos de Alhazen tornam-se o principal guia para os cientistas preocupados com os fenômenos ópticos. O De aspectibus foi lido por todos os grandes ópticos, entre eles Roger Bacon, Pecham e Vitélio.

A base da teoria da visão de Roger Bacon (1214-1292) é extraída dos aspectos anatômicos, filosóficos e matemáticos de Alhazen. Em suas principais obras sobre óptica, Perspectiva e De multiplicatione specierum (Acerca da multiplicação das espécies), o objeto visto transmite "espécies" pelos raios luminosos em todas as direções, alcançando a superfície do olho. Cada ponto na superfície do olho é o vértice de uma pirâmide 
visual, com a base na superfície do objeto. Portanto, deve haver uma correspondência ponto a ponto entre os pontos da superfície do olho e os do campo visual (cf. Lindberg, 1976, p. 109).

Ao chegar no cristalino no interior do olho ocorre uma refração das imagens provindas do objeto. Bacon segue à risca a teoria de Alhazen; a diferença é apenas técnica entre os dois, pois Bacon assumirá que o humor vítreo refrata as imagens após o cristalino, no qual se formam as imagens. Essa diferença pode ser apreciada na próxima figura.

Na figura 7, MP é o objeto visto; $A$ é o centro do olho; GF o humor cristalino; $Q V$ é o local da refração no cristalino; $C$ é o nervo óptico; $L S$ o humor vítreo. A imagem de MP entra no olho sem refração pelo cristalino (formando a imagem do objeto); depois disso, a imagem é refratada no humor vítreo e segue até o nervo óptico, onde é, a seguir, interpretada pelo cérebro.

Cabe assinalar que a noção de "espécies visuais" de Roger Bacon servirá como suporte teórico para a explicação de como as imagens visuais são conduzidas até o olho. Ela se assemelha a eidola ou pneuma dos antigos, e também aos "espíritos visuais" de Johanitus. A substituição desse termo ocorrerá com Kepler que, em vez de espíritos visuais ou espécies visuais, usará o termo imago, ou simplesmente imagem.

Depois de Roger Bacon, os principais nomes para a história da óptica foram John Pecham e Vitélio. Os seus trabalhos não foram importantes por inovações técnicas ou por novas posturas filosóficas, mas por transmitirem a óptica de Alhazen e

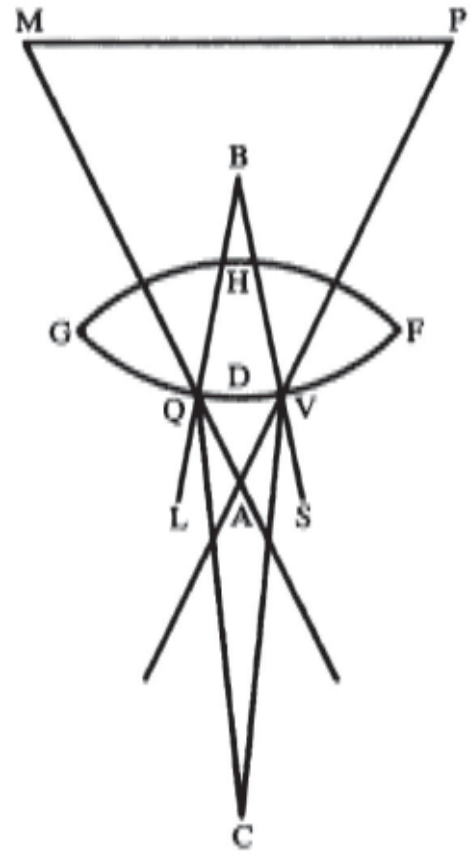

Figura 7. Esquema do processo de visão para Roger Bacon. A concepção do olho como recebendo os raios visuais provindos do objeto visto indica que a teoria da emissão foi abandonada e substituída pela teoria da intromissão. Roger Bacon. Em Pechan, a obra Perspectiva communis (Perspectiva comum) é simplesmente uma síntese do De aspectibus de Alhazen e da teoria de Roger Bacon. Em Vitélio, a Perspectiva (Perspectiva) faz um grande levantamento, uma espécie de compêndio, que reúne todos os grandes trabalhos em óptica, desde Euclides e Ptolomeu até Al-Kind, Alhazen e Bacon. Seu mérito é o de apresentar as principais proposições geométricas de como se forma a visão mediante o paradigma euclidiano de cone visual com o vértice no olho e a base no objeto visto. Vitélio foi um expressivo matemático, e a divulgação da óptica em seus aspectos geométricos foi passada de geração para geração de estudantes da óptica (cf. Lindberg, 1976, p. 117-9). 
Pecham e Vitélio não foram importantes apenas por escreverem manuais de óptica, mas por difundirem o seu estudo nas universidades. A óptica foi incluída nos currículos universitários europeus pela influência desses dois pensadores, tornando essa ciência uma genuína preocupação acadêmica, aumentando o número de pessoas interessadas pelo seu estudo.

\subsection{Perspectivistas e anatomistas}

Do século XIII ao século xvi a óptica não teve avanços substanciais (cf. Lindberg, 1976; Crombie, 1990). Após o século xiıı, com Alhazen no oriente e Bacon, Pecham e Vitélio no ocidente, a óptica viveu durante os séculos xIV e xV um período marcado por pesquisas internas às propostas dos autores do século xiıI. Alhazen continuou nesses séculos, através dos textos de Roger Bacon e, principalmente, dos de Vitélio, exercendo um papel preponderante entre os estudiosos da óptica, tornando-se uma autoridade nessa ciência (cf. Crombie, 1990). A introdução da óptica como matéria oficial no currículo universitário permitiu um aprofundamento da discussão de seus problemas, mas essa discussão esteve assentada apenas no uso de manuais, especialmente a Perspectiva de Vitélio, que acabou tendo o status de livro oficial para o ensino da óptica nas universidades.

Porém, se no campo específico da óptica não houve grandes modificações em relação à obra de Alhazen, a perspectiva forneceu, durante os séculos XIV ao XVI, contribuições relevantes para a ruptura com a teoria de Alhazen feita no século xviı.

A perspectiva foi estudada originariamente pelos artistas, especialmente pelos pintores. A procura de métodos para a representação de figuras tridimensionais, de corpos sólidos, tais como corpos humanos, árvores, igrejas, prédios etc., num plano bidimensional, como uma tela de pintura, levaram os perspectivistas a investirem na procura de técnicas de representação baseadas na geometria projetiva. Representar um corpo sólido numa tela plana implica conhecer os meios de expressar a solidez e a profundidade, o que, como diz Lindberg, foi uma espécie de pesquisa sobre a verdade visual:

[...] a pintura, na procura de expressão de figuras mais humanas, tridimensionais, com qualidade, introduziu visões oblíquas [...] em suas representações arquiteturais; com isso, obteve um sentido de profundidade e de solidez; e ajustou a perspectiva da pintura pelo ponto de vista do observador localizado no centro da capela. Isso foi o início da pesquisa da "verdade visual", um "empenho para imitar a natureza" (Lindberg, 1976, p. 148). 
Ao desejar imitar a natureza, a pintura do Renascimento criou métodos de representação pictórica de figuras tridimensionais, estudando os aspectos geométricos necessários para a expressão almejada. Dois nomes são importantes na teorização da pintura a partir dos cânones da perspectiva, Filippo Brunelleschi (1377-1446) e Leon Battista Alberti (1440-1472).? O primeiro propõe aquilo a que os artistas dão o nome de "perspectiva" para a representação de imagens sólidas no plano, isto é, na pintura. Isso consiste em racionalizar o espaço a ser pintado, obtendo, para tanto, as corretas proporções entre as figuras que estão no interior do espaço pictórico. No mundo real, quando vemos uma imagem qualquer, um lago, por exemplo, com um homem localizado a sua margem e à nossa frente, com uma montanha atrás do lago, temos a visão completa e percebemos qual a proporção entre o homem tanto em relação ao lago quanto à montanha, e esta em relação ao lago. Fazemos isso, entre outras coisas, baseados na distância que estamos da cena. Na pintura, para representar essa cena, temos que criar técnicas que expressem essas proporções; as técnicas pictóricas renascentistas são um conjunto de aplicações de retas, figuras geométricas, jogos de luzes e sombras etc. para dar a "impressão", criar a ilusão, de que o que observamos numa tela tem profundidade. Brunelleschi dedicou-se à invenção de técnicas geométricas de perspectiva.

Alberti fornece aos pintores o corpo teórico necessário para o uso da perspectiva. Em sua obra De pictura, ocorre pela primeira vez na história das artes a sistematização, feita aos moldes dos Elementos de Euclides, da pintura. Nessa obra, definem-se os elementos básicos da pintura: superfície, ponto, reta, jogo de luz e sombras etc. e, de um modo demonstrativo, análogo ao das demonstrações na geometria, são obtidas novas proposições úteis ao artista. A preocupação básica de Alberti é fornecer ao pintor uma teoria, pois este "só se esforça por representar aquilo que se vê" (Alberti,1989, p. 72).

Representar num quadro aquilo que se vê é exercer a perspectiva. Na figura 8, vemos como Alberti constrói numa tela a perspectiva básica para o desenho de um assoalho.

Na figura, vemos o ponto $A$, chamado de "ponto de fuga", que representa o ponto principal para a construção em perspectiva do assoalho; ele é o ponto a partir do qual toda a construção será feita. $D$ é o "ponto de vista", que representa o olho do observador. A construção das tábuas do assoalho deve corresponder à visão que o observador terá do quadro, guardada a distância correta que se deve estar dele.

Como diz Panofsky, o pintor não pintará mais tendo uma imagem ideal, mas representará somente aquilo que vê, "já ninguém julga, pois, que o pintor atue 'a partir da imagem ideal presente na sua alma', como Aristóteles afirmara e Tomás de Aquino e

${ }_{7}$ O leitor interessado na questão da perspectiva como técnica de pintura nos séculos XIV a Xvi poderá consultar, entre outros, Panofski (1964, 1973). 


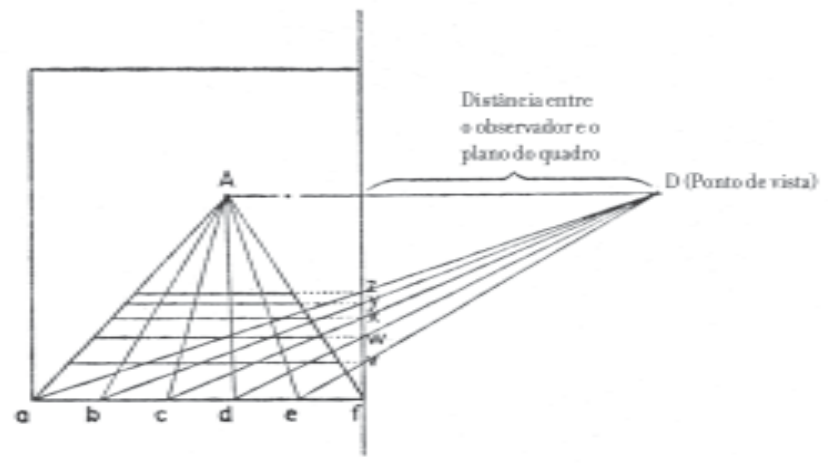

Figura 8. A perspectiva de Alberti. Usando retas e pontos, Alberti apresenta a técnica de perspectiva para pintar o assoalho de uma sala em uma tela. Notar que os pontos A (ponto de fuga) e $\mathrm{D}$ (ponto de vista) determinam a profundidade, que é o principal aspecto da representação tridimensional em perspectiva.

mestre Eckhart corroboraram, mas sim a partir de uma imagem óptica presente nos seus olhos" (Panofsky, 1964, p. 169). Isso terá conseqüências filosóficas para a óptica do século xvır. Kepler não partirá do olho como "vendo imagens interpretadas pela alma, ou pelo cérebro", mas sim daquilo que é pintado na retina.

Outro autor importante nesse período é Leonardo da Vinci (1452-1519). Ele não elaborou nenhuma teoria óptica relevante, mas ajudou a explicar o funcionamento do olho humano por analogia à câmara escura. Vimos que Alhazen também notou nesse instrumento de observação de eclipses um análogo ao olho humano, contudo ele não desenvolveu os aspectos mais interessantes da analogia. Para Leonardo, tal como numa câmara escura, a luz que ilumina os objetos e segue para o olho, ou para o interior da câmara, emite uma quantidade de radiações que, ao entrarem no olho pela pupila, ou na abertura da câmara, é refratada para alguma parte do olho, ou da câmara, conforme visualizamos na figura abaixo.

Leonardo é ambíguo quanto a qual é a parte do olho na qual as imagens são refratadas. Ou a imagem é refratada no cristalino, ou é refratada na extremidade do nervo óptico (cf. Lindberg, 1976, p. 166). Desde Galeno ou Alhazen, nenhum óptico negou que o cristalino fosse a parte do olho na qual as imagens são formadas. Ao questionar o papel central do cristalino como a parte que forma a visão no olho, Leonardo criou uma nova questão para ser resolvida pela óptica, a qual será tratada adequadamente no século xviı, por Kepler.

Figura 9. Radiações através das aberturas de uma câmara escura. Leonardo da Vinci notou que os raios vindos dos corpos A, C e E, que entram na câmara escura em $\mathrm{N}$ e P, são refratados para o fundo da câmara. No olho, os raios entram através da pupila, tal como nas aberturas da câmara, e são refratados em seu interior, formando a imagem que seguirá depois até o cérebro pelo nervo óptico.

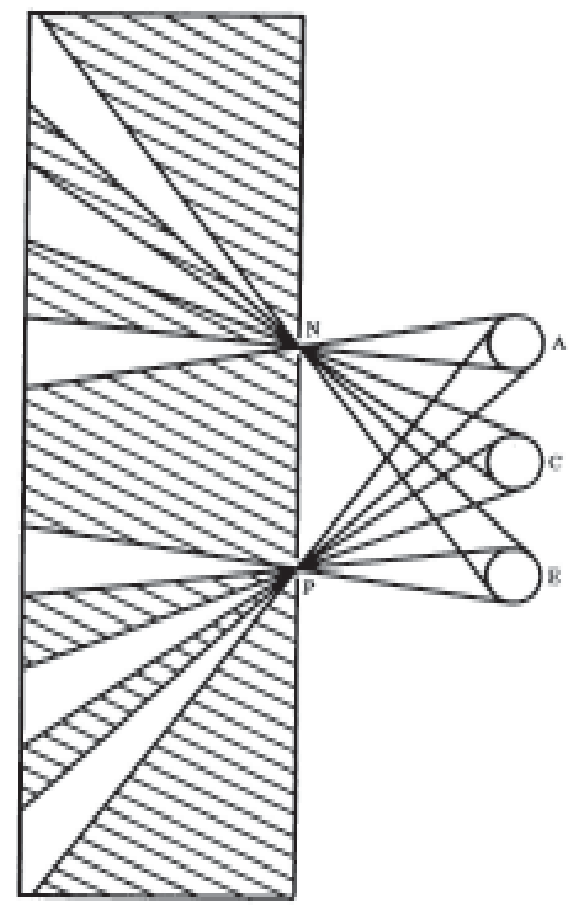


Leonardo ficou intrigado com a inversão das imagens. Se na câmara escura a imagem é invertida, o mesmo deve dar-se no olho, se o considerarmos semelhante a ela. A questão da inversão das imagens no olho só será resolvida com Kepler.

Leonardo também é importante na determinação da variabilidade do diâmetro da pupila; essa variabilidade foi apontada pelos gregos, mas foi completamente ignorada pelos ópticos medievais. A variabilidade é devida à intensidade da luz que chega ao olho (cf. Lindberg, 1976, p. 163). Isso será importante para a anatomia do olho de Plater e Kepler, pois a pupila é, analogamente à câmara escura, a abertura, o local de entrada dos raios visuais provenientes dos objetos iluminados.

Entretanto, apesar de Leonardo contribuir significativamente em alguns pontos para o desenvolvimento da óptica, a sua concepção sobre o funcionamento do olho manteve-se, como diz Lindberg, medieval, pois:

[...] Leonardo não compreendeu os princípios da formação de imagens em superfícies convexas [...] e ele falhou na percepção do problema da multiplicidade de raios provindos de cada ponto do objeto visível, problema que dominou a teoria visual desde Alhazen e que continuou um problema até ser resolvido por Kepler (Lindberg, 1976, p. 164).

Asolução ao problema da multiplicidade de raios visuais determinou, com Kepler no século XviI, uma das principais mudanças em relação à óptica antiga e medieval. Sua solução envolve a pirâmide visual, assunto que foi fundamental para a compreensão do funcionamento do olho no ato da visão.

Entre os séculos xIV e XVI, a anatomia teve um grande avanço. Muitos foram os fatores que contribuíram para isso, sendo os mais importantes:

O aperfeiçoamento na educação médica (a freqüência no aumento das dissecações humanas foi o principal fator para isso); melhor aceso aos textos originais de Galeno; a invenção da imprensa (o que possibilitou uma produção acurada de desenhos anatômicos); e, talvez, o exemplo da investigação anatômica e a hábil representação da anatomia humana pelos artistas do Renascimento (Lindberg, 1976, p. 168-9).

O desenvolvimento da anatomia aumentou muito a compreensão da função das partes do olho humano. Diversos anatomistas investigaram o olho a partir de dissecações, entre os mais importantes estão Mondino dei Luzi (1270-1326), Henry de Mondevilhe (1260-1320), Gabriele Zerbi (1468-1505), Jacobo Berengario da Carpi (14601530), Alessandro Aschillini (1463-1512) e Andréas Vesalius. (cf. Lindberg, 1976, 
p. 168-73). Mas, sem dúvida, o mais importante de todos foi Felix Plater (1536-1614). A sua obra De corporis humani structura et usu, (A respeito da estrutura e do uso do corpo humano) foi muito popular, contendo esquemas sobre o olho e, principalmente, conduziu a uma mudança significativa na concepção da anatomia do olho: a suposição de que as imagens se formam na retina e não, como era aceito desde Galeno, no cristalino. Plater fez essa mudança não porque não seguiu os ensinamentos de Galeno (ele era um galenista convicto), mas porque as dissecações do olho que ele empreendeu o levaram a notar que não há ligação entre o cristalino e o nervo óptico, não existindo, portanto, meio pelo qual a imagem formada no cristalino seja "passada" para o nervo óptico e siga até o cérebro; a ligação se dá, contudo, entre a retina e o nervo óptico.

Mas Plater tratou apenas da parte anatômica do olho, e não dos seus aspectos geométricos. Nesse sentido, o seu trabalho foi necessário, mas não suficiente, pois, como diz Lindberg:

Não existe qualquer evidência que Plater resolveu o problema da inversão, o qual tinha incomodado Leonardo e que foi tratado por Kepler. A teoria de Plater simplesmente não se estende para a matéria geométrica [...], e não temos qualquer sugestão de que nos trabalhos de Plater se possa encontrar soluções para os sérios problemas geométricos que devem ser confrontados e resolvidos antes que a teoria da sensitividade retinal fosse uma opção viável (Lindberg, 1976, p. 177).

A teoria de Plater da imagem formada na retina não é uma explicação suficiente para resolver os problemas geométricos, que são gerados pelo cone visual euclidiano. Nesse sentido, algo mais se fazia necessário.

\section{Conclusão}

Os desenvolvimentos ópticos dos gregos até o século xvi que vimos abreviadamente neste texto e que representam a situação que Kepler encontrou na óptica de sua época, podem ser resumidos nos seguintes pontos:

(1) em termos anatômicos, a formação da imagem no olho teve como primeiro foco o cristalino, com Galeno, Alhazen e seus intérpretes; em seguida, a formação da imagem passa a ser entendida como ocorrendo na retina, com Felix Plater;

(2) em termos matemáticos, o cone visual euclidiano era aceito como o modelo geométrico para a descrição das refrações do objeto visto até o olho. Além 
disso, a teoria da perspectiva desenvolvida durante o Renascimento forneceu técnicas importantes para representar objetos tridimensionais em planos bidimensionais.

(3) em termos filosóficos, Alhazen e seus seguidores, principalmente Roger Bacon, Pecham e Vitélio, deram mais ênfase para a teoria da intromissão. Com isso, o olho passou a ser entendido como um elemento passivo. Aliado a isso, está a analogia com a câmara escura.

Esses três aspectos já estavam presentes nos estudos ópticos do final do século xvi. O problema que se tinha era relacioná-los, sintetizá-los num corpo teórico que explicasse e descrevesse o mecanismo da visão. Num primeiro momento, os gregos estipularam os possíveis campos em que um fenômeno óptico pode ser entendido: filosófico, anatômico e geométrico; porém, a relação entre eles estava, de uma certa forma, difusa. Alhazen funde um pouco mais a relação entre anatomia e geometria, mas utilizando-se do cone visual euclidiano que não se mostrava, justamente pela localização do vértice do cone no olho e a base no objeto visto, adequado para dar conta de todos os possíveis raios visuais. Filosoficamente, o olho deixa de ser entendido como um agente ativo, tal como expresso principalmente pela teoria da emissão, e passa a ser entendido por analogia a um artefato mecânico, a câmara escura. A coordenação desses três pontos constitui a agenda de pesquisa dos ópticos do século xvir.

\author{
Claudemir Roque Tossato \\ Bolsista da FAPESP, \\ Pós-doutorando do Departamento de Filosofia \\ da Universidade de São Paulo. \\ toclare@uol.com.br
}

\begin{abstract}
In this article, I deal in general lines with the role oh human eye in the development of optical theories in the period from ancient Greek to the end of sixteenth century. Two great moments of the history of optics are set for: Antiquity and the thirteenth century. I try to rise some of the main points related to the importance of human eye in the act of vision, relating these points to three research traditions which served as a base to the elaboration of optical theories, the first philosophical, the second anatomical, and the third matematical. The intention is to map the situation of optics as the function of the human eye before Kepler's revolutionary works at the beginning of seventeenth century.
\end{abstract}

KeYwords • Optics. Vision. Camera obscura. Anatomy. Perspective. Euclides. Alhazen. Kepler. 


\section{REFERÊNGIAS BIBLIOGRÁFIGAS}

Alberti, L. B. Da pintura. Campinas: Edunicamp, 1989.

Bradbury, S. \& Turner, G. L. E. Conference of The Royal Microscopical Society. Cambridge: Cambridge University Press, 1967.

Castiglioni, A. História da medicina. São Paulo: Companhia Editora Nacional, 19411. v. 1.

Cohen, M. R. \& Drabkin, I. E. A source book in greek science. New York: Mcgraw-Hill, 1948.

Свомвіе, A. C. The mechanistic hypothesis and the scientific study of vision: some optical ideas as a background to the invention of the microscope. In: Bradbury, S. \& Turner, G. L. E. Conference of The Royal Microscopical Society. Cambridge: Cambridge University Press, 1967. p. 3-112.

. Historia de la ciência de San Agustín a Galileo. Madrid: Alianza Editorial, 1987. v. 1.

Expectation, modelling and assent in the history of optics. Part I: Alhazen and the medieval tradition. Studies in History and Philosophy of Science, 21, 4, p. 605-32, 1990.

. Expectation, modeling and assent in the history of optics. Part II: Kepler and Descartes. Studies in History and Philosophy of Science, 22, 1, p. 89-115, 1991.

Hatfield, G. \& Epstein, W. The sensory core and the medieval foundations of early modern perceptual theory. Isis, 7०, 3, p. 363-84, 1979 .

LiNDBERG, D. C. Alhazen's theory of vision and its reception in the west. Isis, $5^{8}$, p. 321-41, 1967 .

. Alkindi's critique of Euclid's theory of vision. Isis, 62, p. 469-89, 1971.

Theories of vision from Al-Kindi to Kepler. Chicago/London: University of Chicago Press, 1976.

Panofsky, E. Renascimento e renascimentos na arte ocidental. Lisboa: Editorial Presença, 1964.

. La perspectiva como "forma simbolica". Barcelona: Tusquets Editor, 1973.

Pirenne, M. H. The scientific basis of Leonardo da Vinci's theory of perspective. Isis, 10, 3, p. 169-85, 1952.

Platão. Timeu. Belém: Editora da Universidade do Pará, 2001.

Ronchi, V. Storia della luce. Bologna: Zanichelli, 1952.

Optics: the science of vision. New York: Dover, 1959.

Singer, C. Uma breve história da anatomia e fisiologia desde os gregos até Harvey. Campinas: Edunicamp, 1996.

Sмiтн, A. M. The psychology of visual perception in Ptolomy's optics. Isis, 79, 2, p. 188-207, 1988.

UnGURU, S. Vitelo and thirteenth-century mathematics: an assessment of his contributions. Isis, 63, 4, p. $496-508,1972$. 